Paper presented at the 6th Topical Meeting on the Technology of Fusion Energy, San Francisco, CA, March 3-7, 1985; also for publi ation in Fusion Technology.

1485010494

CONF-850310--69

DE85 010494

\title{
MIG: MCNP INPUT GENERATOR FOR EFFI MAGNET GEOMETRIES*
}

\author{
H. Attaya \\ Fusion Technology Institute \\ University of Wisconsin \\ Madison, WI 53706 \\ and \\ Y. Gohar \\ Fusion Power Program \\ Argonne National Laboratory \\ Argonne, IL 60439
}

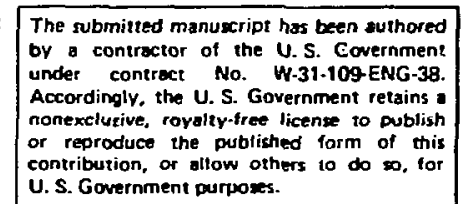

DISCLAIMER

\begin{abstract}
This report was prepared as an account of work sponsored by an agency of the Unjted States Government. Neither the United States Government nor any agency thereof, nor any of their employees, makes any warranty, express or implied, or assumes any legal liability or responsibility for the accuracy, completeness, or usefulness of any information, apparatus, product, or process disclosed, or represents that its use would not infringe rivately owned rights. Reference herein to any specific commercial product, process, or service by trade name, trademark, manufacturer, or otherwise does not necessarily constitute or imply its endorsement, recommendation, or favoring by the United States Government or any agency thereof. The views and opinions of authors expressed herein do not necessarily state or reflect those of the United States Government or any agency thereof.
\end{abstract}

* Work supported by the U.S. Department of Energy. 
MIG: MGNP INPUT GENERATOR FOR EFFI MAGNET GEOAETRIES

Hosny Attaya

Fuston Technology Institute Univeraity of Hisconsin Mad18on, FI $\mathbf{5 3 7 0 6}$

(608) $263-6398$
Yousry Goher

Pusion Power Progran

Argonne Rat liunal Laboratory

Argonne, IL 60439

(312) $972-4816$

\section{ABSTRACT}

A computer code, MIG, has been developed to interfece the magnet design and the three dimensional Monte Carlo code MaNP to perform neutronics design analysea. MIG prepares all the required MCAP cello and surfaces to simulate the cagnets deacribed in EPPI Input. Extra zones with different atertals could be added to envelop or divide the winding packs of the agnets. Exanples of the input and output of MIG used by MCNP are given to iliustrate the different capabilities of MIG.

\section{INTRODUCTION}

In all of the agnetic fusion reactor desigas, data transfer is required between d1fferent subsystea design codes. Th1s process requires a great deal of effort and etrors could occur in transferring data fros one or more codes to another. To avold these difficulties and to anke the design process consistent and accurate, an interface conputer code(s) should control these processes. The aaln functlons of the Interface(s) are to prepare Input, Iaterpret output, and ake output avallable as input for other code(s) which needs the data. Thus, it appess that the initial tep in developing this capability is to Interface Input/output of the different codes Involved in the design process. Once these interfaces are establiched, the conatruction of one design code to control the reactor deaign process and drive the subsystea design codes would be posstble.

This deaign code can be used in an 1terative cheme to perfore paranotric ourvey or design etudy but it rould be too expensive and iopractical. Thus, the exictence of such a code would not elininate the need for systems codes such as the Tokanak Syotes Code or the Tandea Mirror Reactor system Code developed at the national laboratories. Usually these syam tens codes contain almplified codell for plases physics, anzets, etc. which allow an inexpensive paranetrlc uurvey to choose int- t1al design̈ paraweters. The design polnt resulting from the oysten code should then be exanl ned and verifled by the deelgn code.

Ae a flrat step, two conputer codes were developed which provide interfaces betreen magnet, neutronica, and gtreas analysis codes. The fizat one is NIG (Nastran Input Generator), which establiahes the Interface between the agnet deaign code EFPI $^{2}$ and the etress analyale code NASTRA. 3 The aecond code, the subject of this paper, 1s MI (KCMP Input Generator). MIG provides the interface between the conductor geosetries used by the EFFI code, 'the atructure requitements as defined by the NASTRAN anslyes, gad the nagnet geonetricel adels used by MCNP."

Figure 1 shows the date tranafer procese between agnetice atructure analyaes and neutronles eatabliahed by NIG and MIG. The EFFI Input describes the conductor specifications for the agnete wich are used by MIG to generate the MCNP input oodeling the manets. Other components of the egrets (case, Insulator zone, dewar, etc.) calculated or specified as input date ore modeled explicltiy by MIG for KCAR calculetions.

A Asgnet is defined In EFTI to be a sroup of conductor elewents. These elemente could be clrculer arce and/or straight segente with rectangular crose sections. MIG uses all pertinent eleaent quantities as defined for EFPI to generate the surface equation of ench elewents. Then, Mrg sorte these surfaces, forms one cell for esch conductor element according to the MaNP rules, and conblnes the different cells of each coll in on cell describint the linding pack. Aleo, IIG can add enrelopes or divide the rinding pack for eech coll to sinulate the coll case, therael lasulator rap, and coll devar if dealrad. Material number and denatty cen be eselgned for each errelope well as for the vidin anterlal. Inte procedure produces a complete guontrical model for HCMP to use. Betalls of this procedure are stuen below, tollowed by a fer examples for 1llustration purposes. 


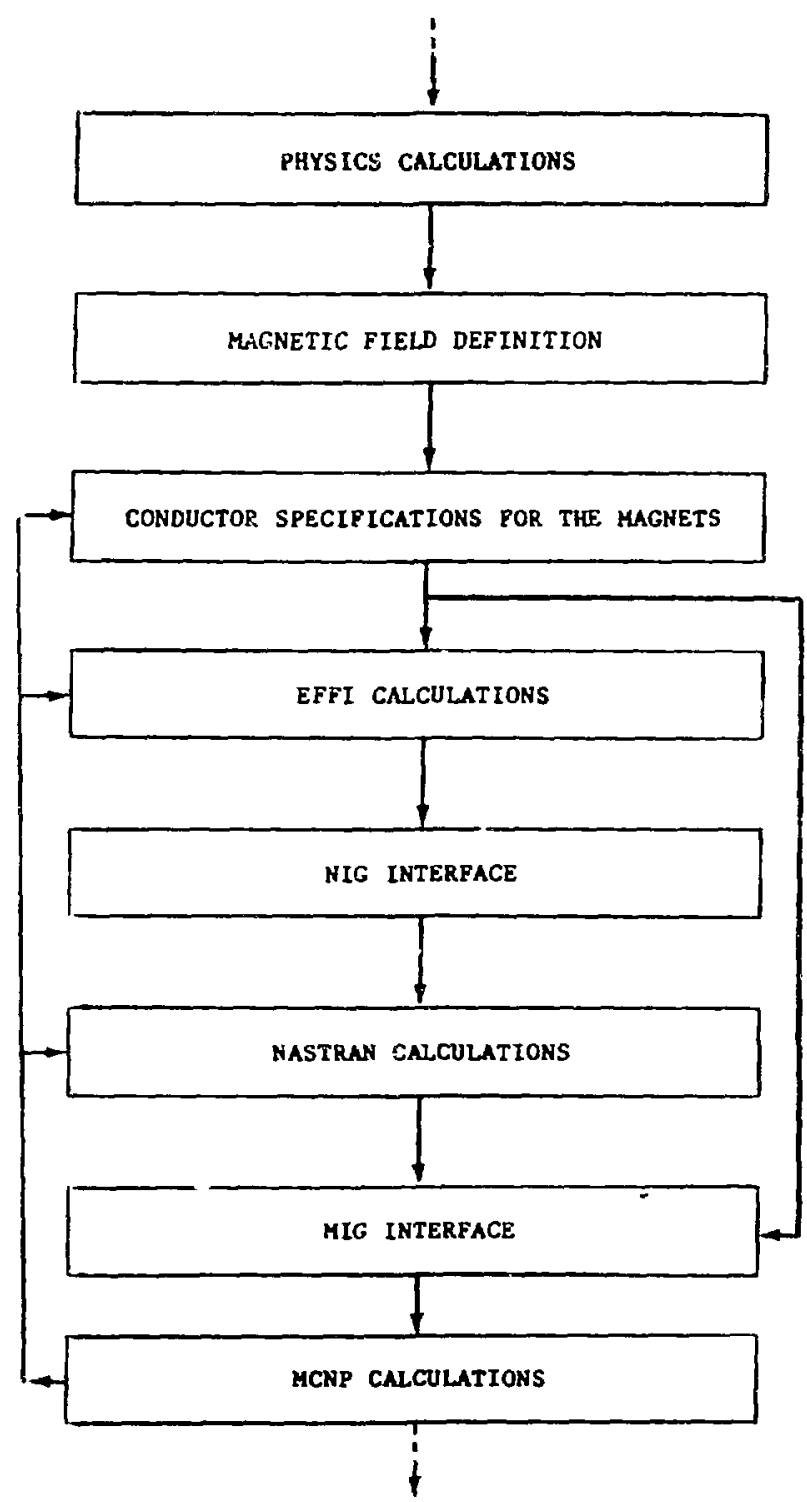

F18. 1. Data tranafer flou chart between angnetice, structure analysee, and neutronlcs eatablished by NIG and MG.

GEOMETRY IN EFPI AND MCNP

To describe how MIG worke, it is conscructive to how how a coll could be presented In EFPI, and how geometries are described in MCNP. The readers should refer to references 2 and 4 for more detalla ubout EPFI and HCMP.

Ae mentioned before, a coll in EFPI con-1ste of one or vore elements. The different types of elexents are loop, arc, and general current element (GCQ). The loop lo epeciffed by tis center $(x, y, z)$, the radius (a), the Euler orientation angle $(\alpha, \beta)$, the axial, and the radial diaensions of the conductor cross eection $(a,-2)$.

The arc is described in the sane way with the addition of the stacting and the ending angles of the arc $\left(\phi_{1}, \phi_{2}\right)$. Figure 2 hows all the above variables necessary to describe a loop or are element.

Pigure 3 shows the variables used to describs a GCE. These are che centroid coordinates $(x, y, z)$, the Euler angle $(a, b, Y)$, the wdth, the thickness, and the length of the eleaent $(\Delta 1,02,83)$. There 18 another type of GCE in EFTI which 16 not considered in the present version of MIG, alnce ost of the fusion agnets can be constructed by using the above elements. However, the inclusion of this GCE in HIG is simple.

Stuilar to EFPI elewents, "cells" are used by MCNP to define any geosetrical object. A cell $1 \mathrm{a}$ bounded by first- or second-degree surfaces and 19 defined by the intersections, the unions, and the compleatents of the regions bounded by these surfaces. Thus, the basic entities used in MCNP to descrive an object are the ourfaces bounding this object. In addition, the regions outelde the objects or the regione between different object should be defined in the aase way. A complicated body can be defined by unions, Intergections, and conpleaents of cells within the body Instead of defining the whole body as one complicated cell.

To wodel a coll given in EPFI Input to MCNP, MLG generates all the urfaces bounding each EFPI elewent; each surface has an Ident $1-$ flcation nuber. Hext, MIG corta these urfaces and checks $1 \mathrm{f}$ any of thece urfaces had already been generaced. In wuch case, MIC disregerds that surface(s) and uses the old one (s).

Th1s step Insures that no redundancy in Burfaces could occur and the alniaun nunter of surfaces 1s used to codel the elesenta. A cell 1s foraed for each eleatent and the union of all cell. 1 a ade to generate the coll.

\section{EXAYPLE OP AUC IRANSFORAITION}

The are how in Fig. 2 is conoldered to descrlbe the sequence of the process descrlbed above. There are two cylinders, and four planee bounding this are. The firat step is to set up the coordinate traneformation antrix from the local arc coordinate syaten to the global one. Given the Euler angles $a, B$, and $\gamma,(\gamma=0$ for arce), the elenerte of chis antrix are: 


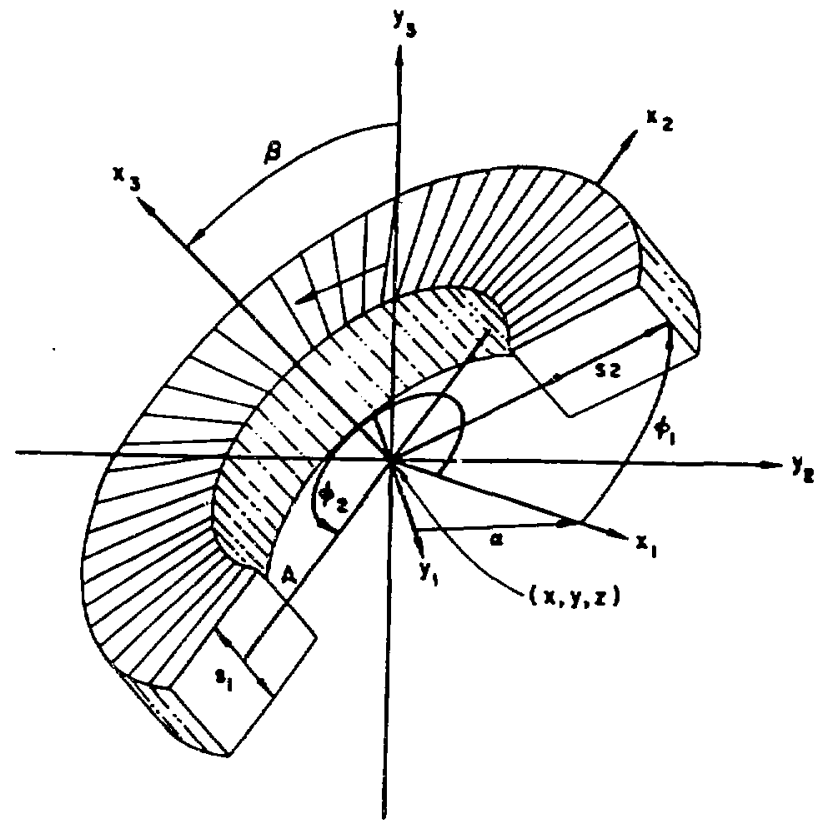

FIg. 2. Loop or arc variables from Ref. 2 .

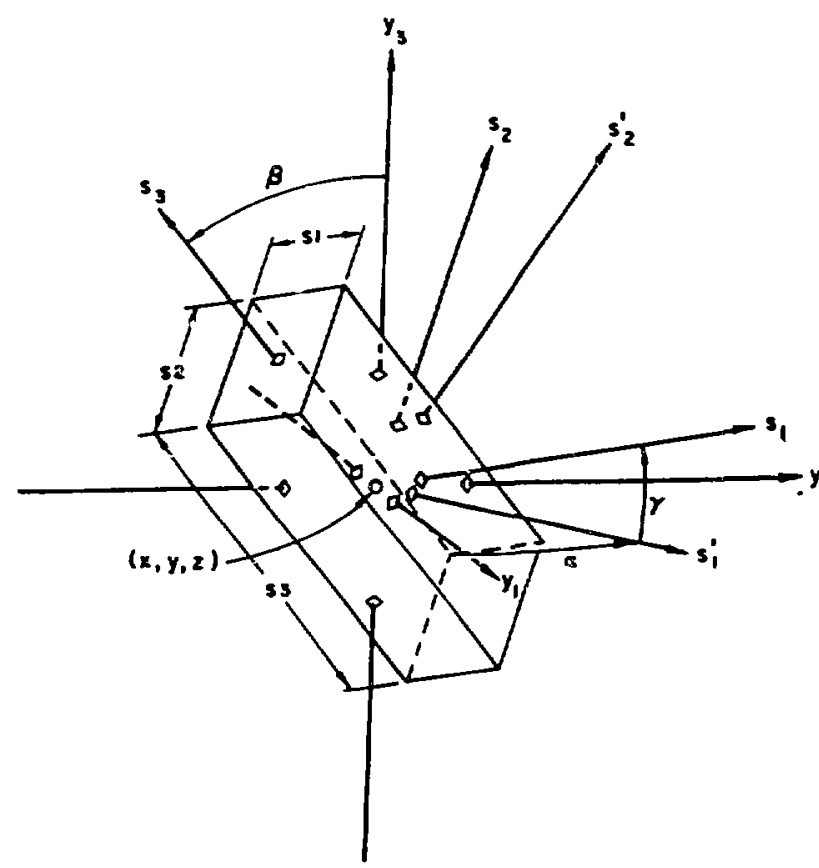

P1g. 3. GCE variables fron Ref. 2.
$T(1,1)-\cos Y \times \cos \alpha-\cos B \times 81 \mathrm{na} \times 81 \mathrm{ry}$

$T(1,2)=-\sin \times \cos a-\cos B \times a 1 n \pi \times \cos y$

$T(1,3)=\sin B \times 81 \mathrm{na}$

$T(2,1)-\cos \gamma \times s 1 n a+\cos B \times \cos a x s 1 \pi$

$T(2,2)=-81 \mathrm{my} \times 81 \mathrm{ma}+\cos 8 \times \cos a \times \cos \mathrm{y}$

$T(2,3)=-\ln \theta x \cos a$

$\mathrm{T}(3,1)=1 \mathrm{my} \times \mathrm{B} 1 \mathrm{nB}$

$T(3,2)-\operatorname{ccay} \times 81 \mathrm{nB}$

$T(3,3)-\cos B$

The direction cosines of the arc axis $1, n, n(0,0,1$ in the local coordinateg) can be evaluated uaing the watix $T$. The general equation of a cylindrical surface can be witten as follows:

$A X^{2}+B Y^{2}+C Z^{2}+D X Y+E Y Z+F Z X+G X \dot{r} H Y+K Z+L=0$.

Given the direction cosines of the cylinder axia $1, x, n$ and the coordinates $x, y, z$ of a point on 1te axis, the coefficients of this equation can be evaluated as follows:

$$
\begin{aligned}
& A=n^{2}+a^{2} \\
& B=n^{2}+1^{2} \\
& C=a^{2}+1^{2} \\
& D=-21 \\
& B=-2 n \\
& P=-21 n \\
& C=-2\left(n^{2}+n^{2}\right) x+2 n 1 z+21 n y \\
& H=-2\left(n^{2}+1^{2}\right) y+2 a n z+21 a x \\
& K=-2\left(a^{2}+1^{2}\right) z+2 a n y+2 n 1 x \\
& L=x^{2}\left(a^{2}+n^{2}\right)+y^{2}\left(1^{2}+n^{2}\right)+z^{2}\left(1^{2}+m^{2}\right)- \\
& \quad-2 m n y x-2 n 1 z x-21 a x y-r^{2}
\end{aligned}
$$

where 5 is the radius of the cylinder. only the lat coefficient differe for cyllnders of comon axis. Thus, it is etralgheforvard to evaluate the coefficiente of the two cylindrical surfaces bounding the arc. If the cylinder axis to parallel to one of the principal axes, impler fores recognized by MCAP are uaed.

The coefficients of the upper snd the lower planes bounding the arc at right angle with its axis can be evaluated by using the direction cosines $(1, n, n)$ and the coordinates of a polnt on each. similarly, the coefficleate of the realining bounding planes could be couputed uning the nomala and the coordinates of a point on each plane.

The couponents of the nozale to these planes in the local arc cootdinate syated are cos $\left(\psi_{1}\right.$ or $\left.\iota_{2}\right)$, ein $\left(\psi_{1}\right.$ or $\left.\iota_{2}\right)$, and 0 . Ueins the tranefoltation metrix $I^{2}$ the corresponding 
values of these conponents in the global coordinate systea could be obtalned. siallar steps could be done for the GCE with all the bounding surfaces being planes.

\section{ADDING LAYERS}

The dinengiong given in the EFFI input are the winding pack dimensions, l.e. the current carrying part. To laclude all the layers that could possibly envelop the winding pack in a real magnet, e.g. case, insulator, dewar, ecc., a simple Instruction could be added In front of the coll data in the EPPI input. These ingtructions control the number of layers to be added, the thickness, and the watertal of each.

Addiclonal surfaces and cells are then generated by MIG to model thess layers. The winding pack itself could be divided into wore than one zone using the same procedure. This could be benefictal in determining a certain nuclear response (e.g. nuclear heating) in different parts of the winding pack.

\section{ILLUSTRATIVE EXAMPLES}

Two examples are discussed to 11 lustrate the use and the main features of the MIG interface. The first example has a siaple solenold with the following dimensions: a 150 co Inner radius, a $450 \mathrm{~cm}$ outer radius, and a $200 \mathrm{~cm}$ winding pack length. In this example, the solenold axis 18 the $z$ axis which siaplifles the ourface equations for MCNP. Table 1 gives the Input and the output of the MIG interface for this solenoid. The MIG input consists of an EFFI Input with a swall addition to lllustrate the waterlal assignments and the layer option. Records 4 ard 5 in the HIG Input of Table 1 define the densitiea for the two naterials used in this example. Material 1 is asigned to the wilding pack by Record 6. The winding pack 1s asalgned a zero zone number where positive and negative numbers are given to the zone outside and Inglde the winding pack, reapectively. Record 7 defines a layer of 10 ca thickness of naterial 1 measured from the surface of the winding pack. The rilnus sign in front of the zone nusber Indicates that this zone 18 concalned Inside the winding pack boundariea. Record 8 defines vacuum gap (material 0) of $10 \mathrm{cw}$ thickness weasured from the surface of the winding pack. Th1s gap is located outside the winding pack as indicated by the positive $81 \mathrm{gn}$ of the zone number. Record 9 defines. case for the winding of $10 \mathrm{~cm}$ thickuess of saterial 2. The output frod MIG 1s also shown In Table 1. Cells 1 and 2 are the winding pack dividing to two vections as defined in the MII Input. Cell 3 is the vacuum gap and Cell 4 is the case. Cello 5 and 6 are the Inner and the outer apace eurrounding the solenold. Figure 4 show two crose sections In the colls as plotted by MaNP.
TABLE 1. MIG EXAKPLE POR THE SOLENOID

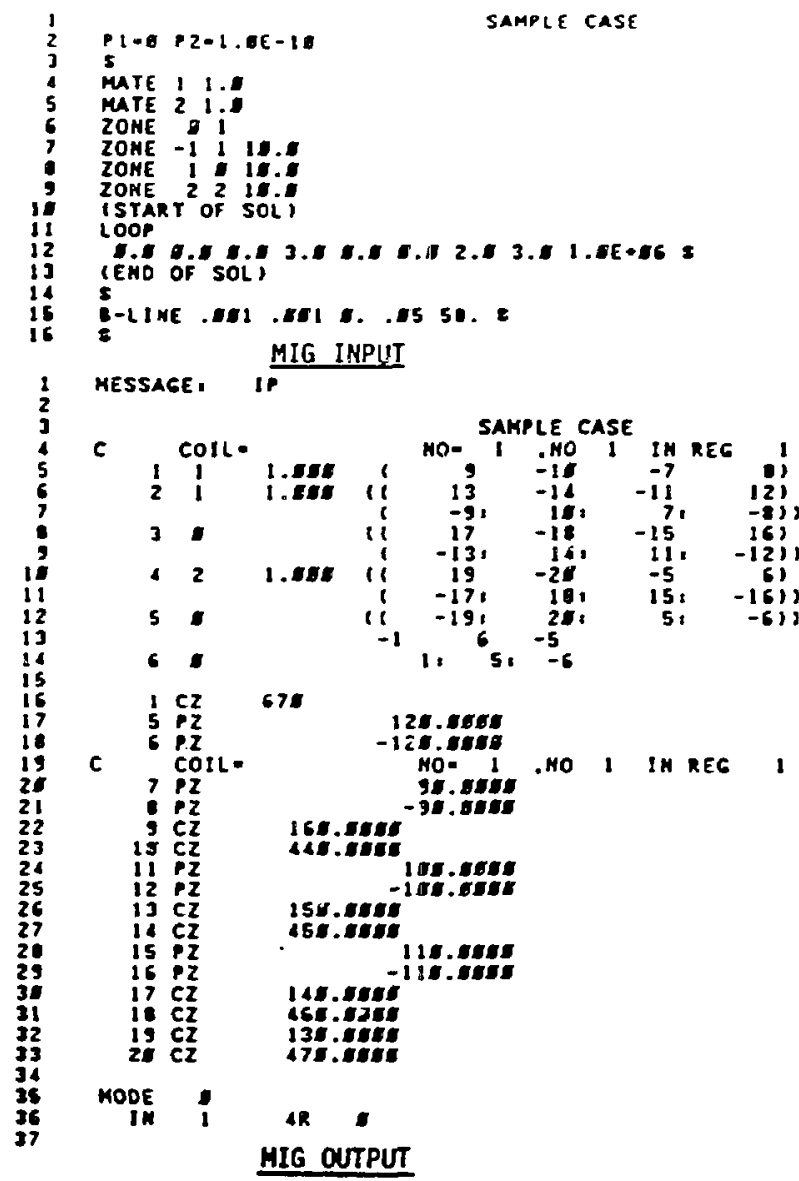

The second example is the geosetrical model of the end cell of the FPD-I (the Fusion Power Demonatration, the irror ETR) developed for the neutronics analyoes 5 . Flgure 5 ahows the s1x cee colls of the end cell as defined in the EFFI Input and the geometrical oode? generated by MIG and plotted by MCNP. In this model, mall layer in the winding pack, a vacuur gap, and a coll case are included for each coll. Also, ahielding zone was added to the MIG output between the coll and the plasea for the coll protection. In this nodel, one quarter of the geometry lo wodelled to take advantage of the syasetry as ahown in P18. 5; ch1. 18 another feacure of MIG. In fact, the user has the cholce of utilizing the eyametry $1 \pi$ the geogetry around any of the an planes to eave on the nuaber of cells and surfacea uned by MCNP to nodel the geonetry.

\section{CONCLUSIONS}

The MIG code wo developed to interface the agnetice and the neutronica analyses. It providee an accurate three-dieenelonal 




Cross Section In $z=0$ Plone

F1g. 4. MCNP plots resulted frow the MG geowetrical model of the solenold.

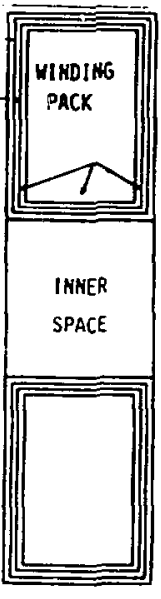

Cross Section in $y=0$ Plane

geawetrical wodel of the magnets for the MCAP calculations. It was used successfully for the FPD-I design to analyze the difficult Beometry of the end cel1. I

ACKNOFLEDÉEHENTS

Th1s work was supported by the U.S. Departaent of Bnergy.

REPERENCES

1. H. ATTAYA, "HIG; NASTRAN Input Generator," to be published.

2. 5. J. SACKETT, "EPPI - A code for Calculating the Electromagnetic Eleld, Force, and Inductance in Coll Systems of Arbitrary Geometry," UCID-17621, Lawrence L1veraore Laboratory (1977).

3. MSC/NASTRAN, The MacNeal-Schuendlet Corporat ton (1983).

4. "MCNP - A General Monte Carlo Code for Neutron and Photon Transport," LA-7396-M, Los Alanos National Laboratory (1981).

5. Y. COHAR, Neutronics Activitles for Next Generation Devices," Proc. of the 6th Toplcel Mtg. on the Technology of Pusion Energy. San Prancisco, Ch, March 3-7, 1985.
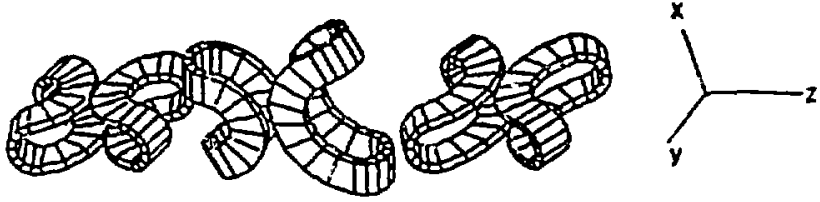

FPD-I End Cell colls
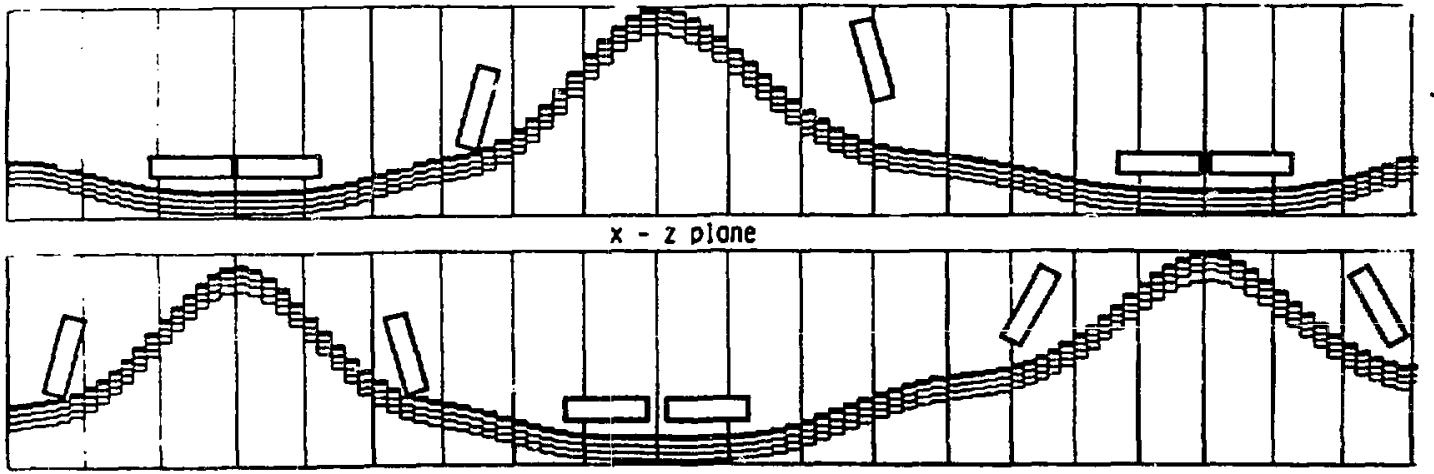

$y-2$ plone

F18. 5. FPD-I Cee colla and MCKP plota for the geometrical aodel generated by MIG. 


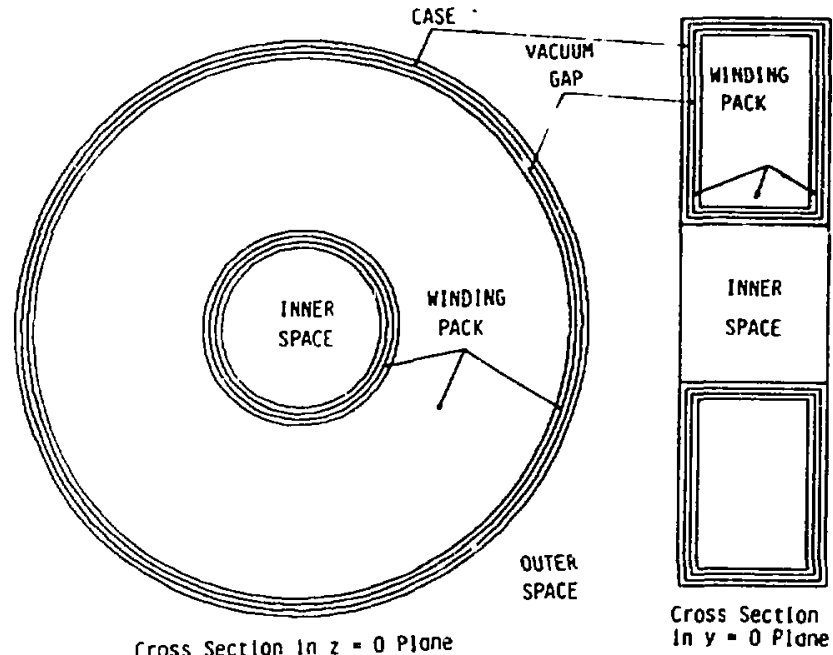

F1g. 4. MCNP plots resulted from the MIG geometrical model of the Bolenold. geometrical wodel of the magnets for the MOIP calculations. It was used Buccessfully for the PPD-I design to analyze the difficult geometry of the end cell.l

\section{ACKNOWLEDGPESTS}

Th1s work was supported by the U.S. Department of Energy.

REFERENCES

1. H. ATTAYA, NIG; NASTRAN Input Generator," to be published.

2. S. J. SACKETT, "EPPI - A Code for Calculating the Electrosagnetic Pleld, Porce, and Inductance in Coll Sybtems of Arbitrary Geometry," UCID-1762!, Lawrence LIvermore Laboratory (1977).

3. MSC/NASTRAN, The MacNeal-Schwendler Corporation (1983).

4. MCNP - A General Monte Carlo Code for Neutron and Photon Transport, LA-7396-M, Los Alanos Nat Lonal Laboratory (1981).

5. Y. GORAR, Weutrontcs Activitles for thext Generation Devices," Proc. of the Gth Topical Mtg. on the Technology of Pusion Energy, San Franct sco, CA, March 3-i, 1985.


FPD-1 End Cell colls

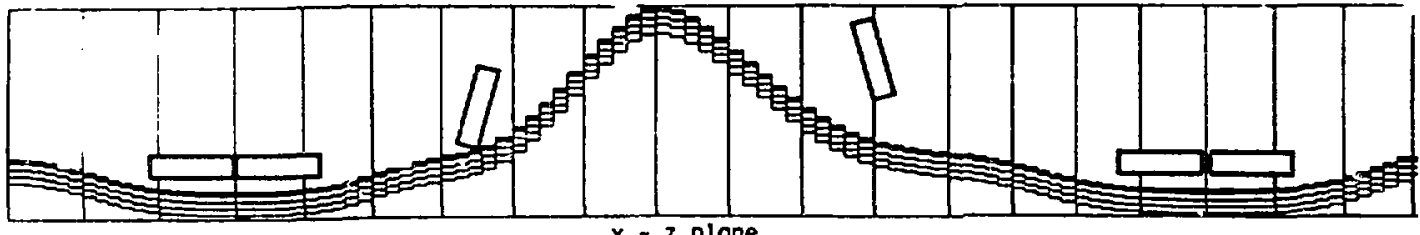

$x-2$ plane

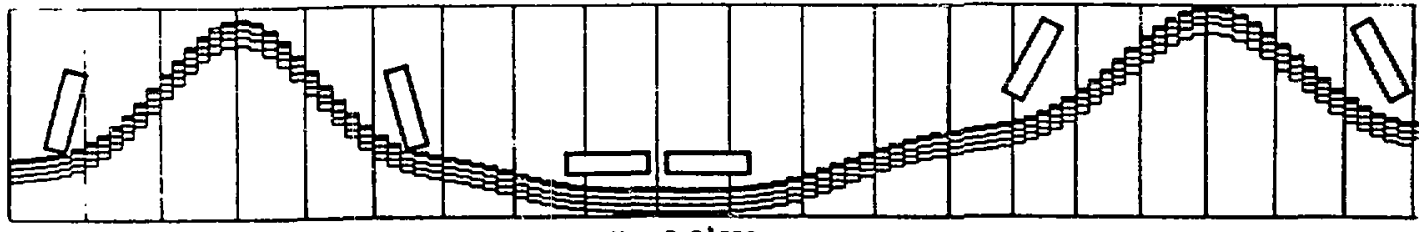

$y-z$ olone

Fig. 5. FPD-I Cee colls and MCNP plots for the geometrical model generated by MIG. 